\title{
バイオ医薬品に含まれる凝集体の適切な分析に向けて
}

\author{
内山 進 $a, b$
}

\section{Toward the Proper Biophysical Characterization of Aggregates in Biopharmaceuticals}

\author{
Susumu Uchiyama ${ }^{a, b}$ \\ ${ }^{a}$ Graduate School of Engineering, Osaka University; GSE East 7F, 2-1 Yamadaoka, Suita, Osaka 565-0871, Japan: \\ and ${ }^{b}$ Exploratory Research Center on Life and Living Systems, National Institute of Natural Sciences; \\ 5-1 Higashiyama, Myodaiji-cho, Okazaki, Aichi 444-8787, Japan.
}

(Received February 26, 2018)

\begin{abstract}
Biopharmaceuticals are often formulated as liquid dosage forms. During manufacturing and storage, protein molecules and active pharmaceutical ingredients form aggregates due to various stresses, including shaking and agitation, as well as by contact with silicone oils coated on pre-fillable syringes. The diameter of protein aggregates ranges from 15-20 nm, and that of dimers comprising a large number of antibody molecules can be up to $100 \mu \mathrm{m}$. Among these aggregates, those with a diameter of $<100 \mathrm{~nm}$ are called nanometer aggregates, while those ranging between $100 \mathrm{~nm}$ and $1 \mu \mathrm{m}$ are called sub-micron aggregates, and those ranging between 1 and $100 \mu \mathrm{m}$ are called micron aggregates. In the last ten years, aggregates have been studied to determine their physical characteristics and their impact on immunogenicity. As a result, novel analytical methods and instruments for such characterizations have been established for a majority of aggregates, including those that are difficult to evaluate. Here, the biophysical features of protein aggregates are explained, followed by an introduction to the different methods for aggregate characterization, including their advantages and actual results. Finally, future perspectives and expectations regarding the characterization of protein aggregates are proposed.
\end{abstract}

Key words — - therapeutic protein; antibody; aggregate; counting; insoluble particulate matter

\section{はじめに}

バイオ医薬品の有効性は十分に認識されている が，一方でその副作用については十分な研究がなさ れておらず，特に，副作用のうちすべてのバイオ医 薬品に共通となる「免疫原性」については不明点が 多い. 10 年ほど前からバイオ医薬品に含まれる夕 ンパク質性の凝集体が免疫原性を発揮する可能性が 指摘されるようになり，欧米の研究者を中心として 精力的に研究が進められてきた. ${ }^{1}$ 併せて, 凝集体 の分析方法の発展も著しい. ${ }^{2}$ 日本においては, 現 在, 同様の懸念から凝集体の評価法の研究が進めら れている. ${ }^{3-6)}$ 本稿では, バイオ医薬品に含まれる タンパク質性の凝集体（タンパク質凝集体）に焦点

${ }^{a}$ 大阪大学大学院工学研究科生命先端工学専攻（广5650871 大阪府吹田市山田丘 2-1 GSE イースト 7F), ${ }^{b}$ 自 然科学研究機構生命創成探究センター（下444-8787 愛 知県岡崎市明大寺町東山 5-1)

e-mail: suchi@bio.eng.osaka-u.ac.jp

本総説は, 日本薬学会第 137 年会シンポジウムS58 で 発表した内容を中心に記述したものである.
をしぼり，その研究背景や規制動向も含めながら， キャラクタリゼーションの現状と展望について紹介 する.

1. バイオ医薬品に含まれるタンパク質凝集体に ついての背景

2006 年頃, バイオ医薬品に含まれるタンパク質 凝集体について，免疫原性との関係に懸念を示した 論文が米国食品医療品局（Food and Drug Administration; FDA）の Rosenbergにより発表された. ${ }^{7)}$ バイオ医薬品が免疫原性を持つと, 投与した医薬品 に含まれるタンパク質が異物として認識されるよう になり，投与しても効果が低下する，さらに，場合 によってはショック症状を引き起こすことから，免 疫原性は抑制する必要がある。免疫原性の抑制のた めタンパク質配列のヒト化が行われるが，完全にヒ トの配列を持つタンパク質であっても繰り返し投与 するうちに，一定の確率で異物として認識されるよ うになる。 タンパク質の免疫原性には依然として不 明点が多いが，上記の Rosenberg の論文が発表さ 


\begin{tabular}{|c|c|c|c|}
\hline \multicolumn{2}{|c|}{ Classification by Size } & \multirow{2}{*}{\multicolumn{2}{|c|}{ Morphology }} \\
\hline Size & Classification & \multirow{6}{*}{\multicolumn{2}{|c|}{$\begin{array}{c}\text { Number of monomeric subunits } \\
\text { Aspect ratio } \\
\text { Surface roughness } \\
\text { Internal morphology } \\
\text { Optical properties } \\
\text { Heterogeneous (e.g., protein-silicone oil) }\end{array}$}} \\
\hline$<100 \mathrm{~nm}$ & \multirow{5}{*}{$\begin{array}{l}\text { Sub-micrometer } \\
\text { Micrometer } \\
\text { Visible }\end{array}$} & & \\
\hline $100 \mathrm{~nm} \sim 1 \mu \mathrm{m}$ & & & \\
\hline $1 \mu \mathrm{m} \sim 100 \mu \mathrm{m}$ & & & \\
\hline \multirow[t]{2}{*}{$100 \mu \mathrm{m}<$} & & & \\
\hline & & & \\
\hline Reversibility & \multirow{2}{*}{\multicolumn{2}{|c|}{$\begin{array}{l}\text { Secondary/tertiary } \\
\text { structure }\end{array}$}} & Covalent modification \\
\hline \multirow{6}{*}{$\begin{array}{c}\text { Reversible } \\
\text { Irreversible } \\
\text { Dissociable under physiological } \\
\text { conditions } \\
\text { Dissociable under defined conditions }\end{array}$} & & & Cross-linked (reducible and nonreducible) \\
\hline & \multirow{5}{*}{\multicolumn{2}{|c|}{$\begin{array}{c}\text { Native/Fold } \\
\text { Partially denatured/unfolded } \\
\text { Denatured/Unfolded } \\
\text { Intrinsically disordered } \\
\text { Ordered (e.g., : Amyloid) }\end{array}$}} & Intramolecular modification \\
\hline & & & Oxidation \\
\hline & & & Deamidation \\
\hline & & & Fragmentation \\
\hline & & & No modification \\
\hline
\end{tabular}

Fig. 1. The Categories of Protein Aggregates

Protein aggregates are classified according to their properties such as size, morphology, reversibility, structures, and covalent modifications. Representative classifications presented by $\mathrm{Narhi}^{16)}$ are indicated.

れた 2006 年，さらに，Carpenter らがバイオ医薬 品に含まれる特定のサイズの凝集体の研究の必要性 を発表した 2008 年以降の世界中の様々な研究の成 果に基づいて, ${ }^{8-10)}$ バイオ医薬品に含まれるタンパ ク質凝集体は投与したタンパク質の免疫原性を高め る，と認識されつつある. 2014 年には FDAより Guidance for Industry として Immunogenicity assessment for therapeutic protein products が発表さ れ，バイオ医薬品に含まれるタンパク質凝集体の適 切なモニタリングと低減の必要性が記載されてい る.11)なお，血液製剤であるイムノグロブリン製剤 では，3 量体以上の重合体の含量を一定以下に抑え る必要があることが生物学的製剤基準に記載されて (る. ${ }^{12)}$ イムノグロブリン重合体の投与が免疫系に 与える影響については，1960 年代には報告があ り, 13) 3 量体以上の重合体は補体タンパク質 $\mathrm{C} 1 \mathrm{q}$ と の結合能が強いことが示されている, ${ }^{14,15)}$ すなわ ち，イムノグロブリンの 3 量体以上の重合体は，抗 原分子に結合していなくても古典経路を活性化する 可能性があり，したがって，こうした基準があるの は納得のできるところである。

\section{2. バイオ医薬品に含まれるタンパク質凝集体の}

\section{分類之分析}

バイオ医薬品に含まれるタンパク質凝集体につい ては，Narhi らにより複数の性質に基づく分類が提 案されている (Fig. 1). ${ }^{16)}$ 凝集体はそれぞれの分類 法において，いずれかのクラスに分類される．凝集 体の分析を実施する際に実践的に重要となるのは可 逆性による分類である。凝集体が可逆的な性質を持 つ場合，分析の際に溶液の希勫を行うと凝集体が解
離するために，希釈率によって凝集体の濃度が異な る結果となる，すなわち，希釈に伴い凝集体含量が 減少することから，希䣋が必要な分析法の場合，希 釈率と凝集体含量の関係を実験的に確認する必要が ある。ほかに分析を行う際に特に留意すべき事項と して，タンパク質凝集体には標準品が存在しないた め絶対定量が難しいことが挙げられる。そのため,

FDAの上述の Guidance では，測定原理が異なる 複数の手法（Orthogonal Methods）を用いて，結 果の比較を行いながら，各分析結果の妥当性を判断 することが奨められている. ${ }^{11)}$

凝集体の分類のうち頻用されるのはサイズによる 分類である. Figure 2 にサイズに応じた分析法をま とめた。 $100 \mathrm{~nm}-100 \mu \mathrm{m}$ の粒子は， subvisible particles（SVP）とよばれることが多いが, Narhi らはサ イズを反映した名称の使用を奨めており，その場合， $100 \mathrm{~nm}-1 \mu \mathrm{m}$ はサブミクロン粒子， 1-100 $\mu \mathrm{m}$ はミ クロン粒子，と区別することとなる. ${ }^{16)}$ 以下，タン パク質凝集体の分析法についてサイズ毎に詳述する.

2-1. $100 \mathrm{~nm}(0.1 \mu \mathrm{m})$ 以下のナノメートル粒子 可溶性でありほとんど光を散乱しないため粒子数 が多く(粒子濃度が高く)ても見た目は透明である. そのため，分離さえできれば，吸光度測定と吸光係 数に基づいた定量が可能である。このサイズ領域の 定量にはサイズ排除クロマトグラフィー（size-exclusion chromatography; SEC) が中心的に利用さ れる．ただし，SECでは $40 \mathrm{~nm}$ 程度より大きい凝 集体はカラムを通過することが難しく，さらに，凝 集体の性質によってはカラム担体への吸着も無視で きないため，凝集体含量を少なく見積もる結果とな 


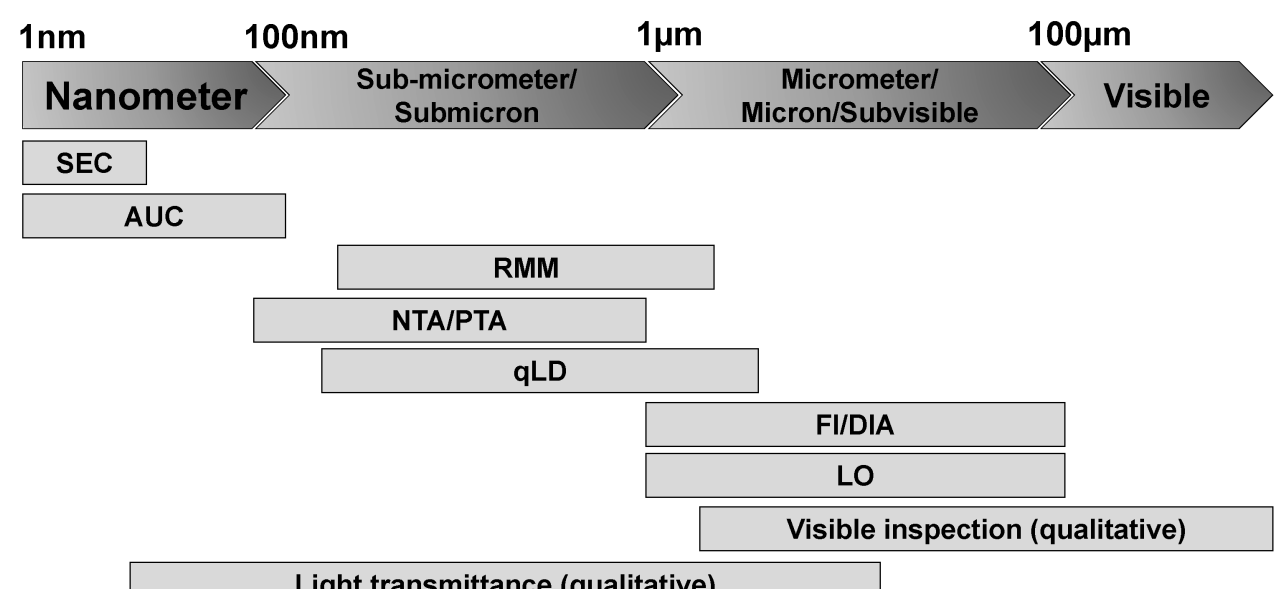

SEC: Size Exclusion Chromatography; AUC: Analytical UltraCentrifugation; RMM: Resonance Mass Measurement; NTA/PTA: Nanoparticle Tracking Analysis / Particle Tracking Analysis; qLD: quantitative Laser Diffraction; FI/DIA: Flow Imaging / Dynamic Image Analysis; LO: Light Obscuration

Fig. 2. The Methodologies for Protein Aggregates Characterization

Protein aggregates have wide range in particle size and are classified according to the size. Since no single method can cover quantification of particles with wide range of sizes, assessment of protein aggregates requires the combination of different analytical methods, deepening on the size distribution. A value obtained from a method should be confirmed using an orthogonal method covering similar size ranges.

ることが多い. ${ }^{17,18)} \mathrm{SEC}$ での分析の妥当性は，回収 率によりある程度は判断できる，例えば，カラム担 体への吸着が起こると回収率が $100 \%$ を大きく下回 ることとなる．SEC の溶離液のイオン強度変更な ぞにより吸着の低減や分離の改善の可能性もある が，そもそも凝集体量既知の標準品がない状況で SEC の結果の妥当性を SEC の条件変更から判断す ることは原理的に不可能である。 そこで，このサイ ズ域の凝集体の定量に, 超遠心分析沈降速度法 (sedimentation velocity-analytical ultracentrifugation； SV-AUC）が用いられるようになってきた. SV-AUC は，超遠心分離とは異なり，超遠心力場 での粒子の沈降パターンをリアルタイムで取得す る. 得られた沈降パターンを解析することで，タン パク質など溶媒中に分散した微粒子の分散状態を定 量的に求めることが可能である. ${ }^{19)}$ SV-AUC では, 密度勾配を作製する必要はなく，樹脂マトリックス を用いないため, 幅広い溶媒組成条件での凝集体定 量が可能である．ただし，得られる結果は，実験及 び解析における条件の違いを受け易いことから，信 頼性が高い実験プロトコルを用いることが望まし い，例えば，安定化剂である糖を含んだ組成の場合 には，その条件に応じた解析パラメータの利用が必 要となる. ${ }^{19)}$

2-2. 0.1-1 $\mu \mathrm{m}$ のサブミクロン粒子 このサイ ズ領域の粒子の分析法として, 共振式質量測定法 (resonant mass measurement; RMM), 粒子トラッ キング解析法 (particle tracking analysis; PTA 又は nano tracking analysis; NTA), 定量的レーザー回折 法（quantitative laser diffraction; qLD）法，などが 利用できる。 RMM は溶媒と粒子の密度差に基づい た測定法であるため，水溶液よりも密度が大きい夕 ンパク質凝集体と密度が小さいシリコンオイルド ロップなどを区別してカウントすることが可能であ る。なお，フローイメージング法（flow imaging; FI，又はデジタル動的イメージング法, digital imaging analysis; DIA, とも呼ばれる) やラマン顕微 鏡ではこのサイズ領域の測定は難しく，したがって， RMM はタンパク質凝集体とシリコンオイルドロッ プの区別が可能な唯一の手法である，qLD は，

0.15-10 $\mu \mathrm{m}$ 程度の粒子を一度に測定可能な手法で あり, 時間や攪汼回数の変化に伴う凝集体のサイズ 分布変化を観測する際に有用である.このサイズ領 域の粒子の絶対数（絶対濃度）の定量は難しく，相 対的な比較のために利用されている.

2-3. 1-10 $\mu \mathrm{m}$ のミクロン粒子 このサイズ領 域の分析は装置開発と測定方法の面から近年最も研 究が行われてきた。特に, 従来から利用されてきた 光遮蔽法 (light obscuration; LO) に代わる手法とし て FI による報告例が増えてきた，FI では，LOより も確実に粒子をカウント可能であり，さらに，粒子 の画像情報が得られることから, 粒子形状やコント 
ラストに基づいた粒子の分類に利用されている. ${ }^{20-22)}$

\section{2-4. $10 \mu \mathrm{m}$ 以上のミクロン粒子 このサイズ} 領域の測定については，米国薬局方 (United States Pharmacopeia；USP）や日本薬局方における「不溶 性微粒子試験」に記載があり，注射剂に含まれる粒 子の数を LO により評価し，一定数以下とする必要 があることが定められている，また，従来から用い られてきた LO について，0.2 mL 程度の少量での 測定が許容されるようになってきた. さらに, 1-10 $\mu \mathrm{m}$ のミクロン粒子と同様に, FI での解析の必要性が 認識されるようになってきた.

\section{3. バイオ医薬品に含まれるタンパク質凝集体の} ガイドラインや局方との関係

既に記載したが 2014 年に FDA よりガイダンス が発表されている. タンパク質医薬品に含まれる不 溶性微粒子の試験法として, USP（米国薬局方） 〈787〉規格が制定され，対応して日本薬局方でも， 6.17 タンパク質医薬品注射剂の不溶性微粒子試験 法の案に関する意見募集が，平成 29 年 9 月に行わ れている。 また，タンパク質凝集体の分析方法につ いては，USP（米国薬局方）〈1787〉に記載がある.

2016 年には FDA の研究者が著者となってタンパ ク質凝集体の評価に関する重要な論文が Journal of Pharmaceutical Science 誌に発表されている. ${ }^{23)}$ そ こでは，現在の局方に規格がある LO による不溶性 微粒子だけでは，タンパク質凝集体の定量としては 不十分で，NTA やFI などの新しい分析手法による 評価の必要性が示唆されている。こうした背景か ら，現在，国立医薬品食品衛生研究所と製薬企業を 中心として，タンパク質凝集体の適切な評価に向け た研究が実施されている. ${ }^{3)}$

\section{4. 摩損度試験器を利用したバイオ医薬品の凝集} 性の評価

バイアルやシリンジに充填されたバイオ医薬品は 輸送，保管，患者への投与，までの間に様々な物理 的ストレスを受けるが，物理的ストレスは，タンパ ク質の凝集へとつながる可能性がある。例えば，輸 送時の振とうによるタンパク質の凝集は以前より指 摘されてきた. ${ }^{24)}$ さらに, 2015 年には, Randolph らにより，バイアルの落下時にキャビテーションが 発生しタンパク質凝集体が発生する, あるいは, 酸 化が起こる，可能性が指摘されていた. ${ }^{25)}$ 衝撃と振 とうは，輸送やハンドリング時にバイオ医薬品が受
け得るストレスである。そこで，近年，筆者らは， バイアルやシリンジの落下による衝撃と振とうの複 合ストレスがバイオ医薬品の凝集を引き起こす影響 を研究している. ${ }^{26)}$ ただし，衝撃や振とうによる凝 集は，不可逆的であることが多く，したがって，凝 集の定量を行ってもバラツキが大きいことから，ま ずは，再現性高く実験結果を得るためのセットアッ プを最初に行った。具体的には，筆者らは，錠剤の 衝撃に対する摩損性やもろさの試験に使用される摩 損度試験器を利用し, 抗体医薬溶液を充填したバイ アルに対して，一定周期で落下と振とうを繰り返す ことで，再現よく，複合ストレスを与えることが可 能となつた。複合ストレスが凝集に与える影響は予 想外に大きく，バイアルのヘッドスペースの大きさ に依存した凝集体発生が確認された。重要な点とし て，振とうストレスだけでは凝集体が発生しない抗 体医薬でも複合ストレスでは凝集体が発生したこと から，複合ストレスが凝集の原因であると言える.

次に，複合ストレスによる凝集体発生の原因を解明 するための実験を行った。一定回数複合ストレスを 与えた後に溶液を取り出し, 同じバイアルに新しい 抗体溶液を充填し振とうストレスのみを与えたとこ ろ凝集体の発生が観測された。一方で，取り出した 溶液を新しいバイアルに充填し振とうストレスのみ を与えたところ凝集体の発生は確認されなかった。

また，今回の筆者らの研究では，複合ストレス後の 抗体の構造に化学変化は観測されなかった。これら の結果は，衝撃時に発生したキャビテーションによ り抗体分子に何かしらの高次構造変化が引き起こさ れ，バイアル壁面に吸着，吸着した分子が振とうに より溶液中に凝集体として放出された可能性を示唆 している.このように，複数の物理的ストレスが組 み合わさると，相乗的にバイオ医薬品の品質を低下 させる可能性があることから，加速試験や過酷試験 などにおいては，実際の現場でバイオ医薬品にかか り得る複数のストレスを想定した試験デザインが必 要となると言える.

\section{おわりに}

以上，バイオ医薬品に含まれるタンパク質凝集体 の分析及び物理ストレスとの関係に関する新しい知 見について概説した。 今後，凝集体の分析方法の更 なる発展と科学的根拠に基づいた製剤に含まれる凝 集体の低減がすすむことが期待される. 
謝辞本研究は, 武田薬品工業株式会社, ユー メディコ株式会社の研究者の方々のご支援を受けて 推進したものです。ここに深く御礼申し上げます。

利益相反 内山 進（武田薬品工業株式会社及 びユーメディコ株式会社から共同研究費を受領).

\section{REFERENCES}

1) Moussa E. M., Panchal J. P., Moorthy B. S., Blum J. S., Joubert M. K., Narhi L. O., Topp E. M., J. Pharm. Sci., 105, 417-430 (2016) .

2) Volkin D., Hershenson S., Ho R., Uchiyama S., Winter G., Carpenter J., J. Pharm. Sci., 104, 290-300 (2015).

3) Ishii-Watabe A., Shibata H., Harazono A., Hyuga M., Kiyoshi M., Saitoh S., Iwura T., Torisu T., Goda Y., Uchiyama S., J. Pharm. Sci., 106, 3431-3437 (2017).

4) Uchiyama S., Krayukhina E., Noda M., Yakuzaigaku, 74, 12-18 (2014).

5) Uchiyama S., Biochim. Biophys. Acta, 1844, 2041-2052 (2014).

6) Uchiyama S., Yakugaku Zasshi, 136, 443-448 (2016) .

7) Rosenberg A. S., $A A P S J ., 8$, E501-E507 (2006) .

8) Carpenter J. F., Randolph T. W., Jiskoot W., Crommelin D. J., Middaugh C. R., Winter G., Fan Y. X., Kirshner S., Verthelyi D., Kozlowski S., Clouse K. A., Swann P. G., Rosenberg A., Cherney B., J. Pharm. Sci., 98, 1201-1205 (2009).

9) Singh S. K, Afonina N., Awwad M., Bechtold-Peters K., Blue J. T., Chou D., Cromwell M., Krause H. J., Mahler H. C., Meyer B. K., Narhi L., Nesta D. P., Spitznagel T., J. Pharm. Sci., 99, 3302-3321 (2010).

10) Joubert M. K., Hokom M., Eakin C., Zhou L., Deshpande M., Baker M. P., Goletz T. J., Kerwin B. A., Chirmule N., Narhi L. O., Jawa V., J. Biol. Chem., 287, 25266-25279 (2012).

11) U.S. Food and Drug Administration (FDA), "Guidance for Industry: Immunogenicity Assessment for Therapeutic Protein Products.": 〈http: / / www.fda.gov / downloads / Drugs / GuidanceComplianceRegulatoryInformation/ Guidances/UCM338856.pdf $\rangle$, cited 25 April,
2018.

12) National Institute of Infectious Diseases (NIID), "Minimum Requirements for Biological Products.": 〈https://www.niid.go.jp/ niid / images / qa / seibutuki / MRBP_english / mrbp_2006.pdf $\rangle$, cited 25 April, 2018.

13) Christian C. L., J. Immunol., 84, 117-121 (1960).

14) Christian C. L., J. Immunol., 84, 112-116 (1960).

15) Wright J. K., Tschopp J., Jaton J. C., Engel J., Biochem. J., 187, 775-780 (1980) .

16) Narhi L. O., Schmit J., Bechtold-Peters K., Sharma D., J. Pharm. Sci., 101, 493-498 (2012).

17) Thirumangalathu R., Krishnan S., Ricci M. S., Brems D. N., Randolph T. W., Carpenter J. F., J. Pharm. Sci., 98, 3167-3181 (2009).

18) Krayukhina E., Tsumoto K., Uchiyama S., Fukui K., J. Pharm. Sci., 104, 527-535 (2015) .

19) Uchiyama S., Noda M., Krayukhina E., Biophys. Rev., 10, 259-269 (2018).

20) Zölls S., Weinbuch D., Wiggenhorn M., Winter G., Friess W., Jiskoot W., Hawe A., AAPS J., 15, 1200-1211 (2013).

21) Torisu T., Maruno T., Yoneda S., Hamaji Y., Honda S., Ohkubo T., Uchiyama S., $J$. Pharm. Sci., 106, 2966-2978 (2017).

22) Maruno T., Watanabe H., Yoneda S., Uchihashi T., Adachi S., Arai K., Sawaguchi T., Uchiyama S., J. Pharm. Sci., 107, 1521-1529 (2018).

23) Kotarek J., Stuart C., De Paoli S. H., Sima J., Lin T. L., Gao Y., Ovanesov M., Liang Y., Scott D., Brown J., Bai Y., Metcalfe D. D., Marszal E., Ragheb J. A., J. Pharm. Sci., 105, 1023-1027 (2016)

24) Kiese S., Papppenberger A., Friess W., Mahler H. C., J. Pharm. Sci., 97, 4347-4366 (2008).

25) Randolph T. W., Schiltz E., Sederstrom D., Steinmann D., Mozziconacci O., Schöneich C., Freund E., Ricci M. S., Carpenter J. F., Lengsfeld C. S., J. Pharm. Sci., 104, 602-611 (2015) .

26) Torisu T., Maruno T., Hamaji Y., Ohkubo T., Uchiyama S., J. Pharm. Sci., 106, 521-529 (2017). 